\title{
The Blue Water Navy and the Question of Exposure to Agent Orange
}

\section{Young $\mathrm{AL}^{*}$}

Young AL Consulting, Inc., Cheyenne, Wyoming, USA

*Corresponding author: Young AL, Ph.D, Principal Scientist, Young AL Consulting, Inc., 1810 Tranquility Road, Cheyenne WY 82009, USA, Tel: 307-638-6279, E-mail: youngrisk@aol.com

Citation: Young AL (2018) The Blue Water Navy and the Question of Exposure to Agent Orange. J Environ Pollut Control 1(1): 102. doi: 10.15744/2639-9288.1.102

Received Date: April 01, 2018 Accepted Date: September 11, 2018 Published Date: September 13, 2018

\begin{abstract}
The United States Department of Veterans Affairs has consistently denied the estimated 90,000 Vietnam veterans who served on ships off the coast of Vietnam that they were exposed to Agent Orange during the Vietnam War, and thus do not qualify for health care and compensation as provided for under the terms of the Agent Orange Act of 1991. Extensive scientific evidence and historical records concluded that it was highly unlikely that Blue Water Navy personnel were ever exposed to Agent Orange while serving off the coast of Vietnam. This review concluded that the Agent Orange Act of 1991 was very poor public policy, and perhaps Congress could have been fairer to all Vietnam veterans including Blue Water Navy veterans with a program of 'Vietnam experience' benefits rather than Agent Orange benefits. However, in the absence of such a reasoned policy, one can only conclude that the current policy for providing compensation for "boots on the ground" veterans of the Vietnam War in the absence of actual exposure information should be extended to Blue Water Navy veterans by congressionally mandated action, rather than on the limited scientific evidence.
\end{abstract}

Keywords: Blue Water Navy Veterans; Agent Orange; Dioxin/TCDD; Vietnam; Exposure to Herbicides

\section{Introduction}

The controversies related to use of Agent Orange during the Vietnam War have involved examination of historical records in the National Archives, extensive medical surveillance of veterans, ongoing reviews of the massive amount of literature associated with the toxicity and environmental fate of the phenoxy herbicides and the toxic contaminant 2,3,7,8-tetrachlorodibenzo-p-dioxin (TCDD), the political issues associated with the Vietnam War, and compensation for Vietnam veterans.

The efforts to get the United States Department of Veterans Affairs (DVA/VA) to acknowledge the estimated 90,000 Vietnam veterans who served on ships off the coast of Vietnam and who claimed exposure to Agent Orange during the Vietnam War have been one of the longest battles in the history of veterans' benefits programs [1]. Blue Water Navy Veterans are not presumed to have been exposed to Agent Orange or other tactical herbicides. Some of the open sea ships docked to the shore of Vietnam, operated in Vietnam's close coastal waters, and sent smaller vessels ashore, or conducted operations on the inland waterways of Vietnam, i.e., the Brown Water Navy [2]. Thus, for a Blue Water Navy veteran who did not set foot in Vietnam or served aboard a ship that operated in the inland waterways of Vietnam anytime between 9 January 1962 and 7 May 1975, the veteran must show a "factual basis" of exposure to receive a full range of medical benefits, and a monthly payment for diseases associated with Agent Orange exposure [2]. Obviously, this requirement to show a "factual basis" is essentially impossible for the Blue Water veteran.

To address the Blue Water Navy veterans' concerns, it is appropriate that the historical records and science behind the VA's position on exposure be examined. However, it is equally important to address the legal positions of the Blue Water Veterans to determine if the refusal by VA is based on fact, rather than on "unsupported legal fiction" and "devoid of any fact-based assessment of the probability of exposure" [1]. Lastly, there are common sense issues that would favor the Blue Water Navy veterans that must be discussed.

\section{Assessment of the Historical Records and Science}

The historical records of the Vietnam War and on the development and use of aerial spraying tactics are extensive [3]. Review of spray swaths by UC-123B/K RANCH HAND aircraft suggested that dissemination of herbicide in Vietnam was very precise and resulted in a pattern of long narrow deposition areas with little herbicide drift outside the treatment areas $[3,4]$. Aerial spraying by RANCH HAND aircraft seldom occurred near the shorelines of Vietnam except in areas dominated by mangrove vegetation [4]. Nevertheless, Blue Water Navy veterans have continued to argue that drift from such applications contaminated their ships miles off shore [5]. 
In 2010, DVA contracted with the Institute of Medicine (IOM) of the National Academies of Science to consider whether Blue Water Navy veterans might have been exposed to tactical herbicides used in Vietnam, specifically Agent Orange and its contaminant, 2,3,7,8-tetrachlorodibenzo-p-dioxin (TCDD) and whether this exposure could lead to an increased risk of long-term health outcomes [6]. The Study Committee faced some very difficult evaluations since the Institute of Medicine or the Department of Veterans Affairs have not defined what constitutes an exposure or harmful dose of Agent Orange or its associated dioxin/TCDD to Vietnam veterans, whether they were ground troops, Brown Water Navy sailors, or now in this situation Blue Water Navy personnel [6]. Thus, the Committee decided to assess the environmental fate and transport of Agent Orange and TCDD and then to determine whether there were plausible exposure routes that Blue Water Navy personnel might be exposed to during military operations [6]. The conclusion reached by the Committee was that "the paucity of scientific data makes it impossible to determine whether Blue Water Navy veterans were exposed to Agent Orange-associated TCDD during the Vietnam War [6]. The Committee however, did conclude that qualitatively, ground troops and Brown Water Navy personnel had more potential pathways of exposure to Agent Orange than did Blue Water Navy personnel [6].

The IOM report was essentially of little value to the Blue Water Navy Vietnam Veterans Association. The Association prepared their own reports and eventually took their case to a Congressional Hearing of the US House of Representatives Subcommittee of the Veterans Affairs Committee [7, 8]. Based upon media reports and the 2013 report on the discussions of claims by the Blue Water Navy veterans, the following assumptions and allegations related to potential exposure of Blue Water Navy veterans to Agent Orange and its associated dioxin contaminant were noted [7-9].

- Massive amounts of dioxin (TCDD) were contained in the Agent Orange and other 2,4,5-T herbicides that were sprayed over the jungles and water ways of South Vietnam, 1961 - 1970;

- The TCDD entered the aquatic environment and through solubility and movement on soil particles. The heavily contaminated water and sediments found their way to coastal lagoons and eventually to the open sea, where Blue Water Navy ships were stationed/patrolling within 5 miles $(8 \mathrm{~km})$ of the coastlines of Vietnam;

- Simultaneously, RANCH HAND aircraft were conducting defoliation missions in and around coastal mangrove for ests, and the drift from such missions directly exposed Navy veterans to the Agent Orange-TCDD;

- And, since the water surrounding the ship was contaminated with TCDD, the multistage flash (MSF) distillation units on the ships concentrated the TCDD in the water by ten-fold.

The findings and conclusions on these assumptions and allegations have been challenged [5].

- Data from the Department of Air Force analyses of 1,082 Agent Orange and 2,4,5-T samples, the mean concen trtion of TCDD in Agent Orange would have been 1.88 parts-per-million (ppm), and the total amount of TCDD from Agent Orange and other tactical herbicides sprayed on $\sim 10 \%$ of the Vietnam forests and mangroves $(\sim 1.3$ million hectares) would have been between 285 - 320 pounds (130 - 144 kilograms) [10,11];

- $\quad$ Records from Operation RANCH HAND (US Air Force UC-123 aircraft used for defoliation in South Vietnam) and US Army Chemical Corps (helicopters) determined that approximately 96\% - 98\% of all TCDD was aerially sprayed on triple canopy jungle or mangrove [11]. Research has indicated that less than $6 \%$ of the herbicide would have penetrated the triple canopy [12]. Because of the extreme sensitivity of TCDD to photodegradation, both in air, or on leaf, soil, or water surface films, it was likely that $95 \%$ of the dioxin in Agent Orange would have persisted for no more than $2 \mathrm{hr}$ in sunlight and $6 \mathrm{hr}$ in shade [13];

- Assume worst case scenario that $10 \%$ of the available dioxin persisted and was bound in soils, this would suggest that 32 pounds of TCDD potentially persisted in 1 million square miles of jungle and associated drainage system [5]. The results of a 2007 study of soil and water samples in the Ma Da area of III Corps, an area repeatedly sprayed with Agent Orange, did not provide evidence that the detected dioxins [mostly Octachlorodibenzo- $p$-dioxin (OCD D, likely from fires] that bound to groundwater colloids were from the Vietnam War [14];

- Studies have shown that TCDD tightly binds to soil/sediment particles and in those matrices has a long persis tence. In a remote test site at Eglin Air Force Base, Florida, massive amounts of Agents Orange and Purple were sprayed in the development of the spray equipment for RANCH HAND. It was found that less than 5\% of the total TCDD persisted for more than 20 years [15]. In studies of the former Agent Orange storage site at Gulfport, Missis sippi, movement of TCDD contaminated soil particles were confined to less than 2 miles $(3 \mathrm{~km})$ within the drain age system, a system that received similar rainfall totals to those in Vietnam [16];

- In 2010, a sophisticated study was reported on the analyses of sediments collected from nine Central Vietnam coast allagoons [17]. The samples were analyzed for polychlorinated dibenzo-p-dioxins (PCDDs), and dibenzo furans (PCDFs). Results found that $90 \%$ of the dioxin was the congener OCDD. The 2,3,7,8-tetrachlorodibenzo-pdioxin (TCDD) was absent or very low. The results supported the hypothesis of strong degradation of TCDD soon after spraying [17]; 
- The IOM concluded that most RANCH HAND sorties were flown in the early morning when a sea breeze was ex pected. Thus, the daily timing of the sorties favored sea-bree ze conditions when the breeze was from the ocean to the land [6]; and lastly,

- The study that TCDD could be concentrated in the multistage flash (MSF) distillation units on the ships was a labo ratory study. Today's most sophisticated analytical capability will permit the accurate measurement of TCDD at less than 1 part-per-trillion (1 ppt) [5]. To put this in perspective, $1 \mathrm{ppt}$ is 1 drop of red dye in a pool of water covering the area of a football field -43 feet $(\sim 13 \mathrm{~m})$ deep. Vietnam had a coast line greater than 700 miles $(1,126 \mathrm{~km})$ and if the Navy ships were located within 5 miles $(8 \mathrm{~km})$ of the shoreline, that would constitute an approximate area half the size of State of New Jersey, Common sense tells us that there was never sufficient TCDD applied in Vietnam to ever be measured in the waters off the coast of Vietnam [5].

From the scientific evidence and historical findings as noted above, it can be concluded that it was highly unlikely that Blue Water Navy personnel were ever exposed to Agent Orange-TCDD while serving off the coast of Vietnam.

\section{Assessment of the Legal Position of the Department of Veterans Affairs}

The Agent Orange Congressional Act of 1991 (Public Law 102-4) provided for presumption of service connection for diseases associated with exposure to the tactical herbicides used in combat operations in the Vietnam War [6]. Initially, the law was interpreted to apply to all service men and women deployed to Vietnam including members of the Blue Water Navy. In 2002, the DVA took the position that for a Vietnam veteran to be presumed to have been exposed to Agent Orange, the veteran must demonstrate that he or she actually "had boots on the ground" in Vietnam [6]. This position was challenged in 2004 in the court case Haas v. Peake (Secretary of VA) and the court continued to uphold the VA position. However, this was reversed in 2006 by the US Court of Appeals for Veterans Claims in part because VA's history of granting presumptive service connection for members of the Blue Water Navy who had received Vietnam Service Medals [6]. In 2008, the original position of DVA was upheld by the US Court of Appeals for the Federal Circuit. This legal action by the Courts effectively excluded most Blue Water Navy veterans from receiving a presumption of service connection for diseases associated with Agent Orange exposure [6].

After the final decision in 2008, the VA processed a backlog of more than 17,000 claims, most primarily from Blue Water Navy veterans. Each one of these claims was reviewed on a case-by-case basis to determine whether a non-presumptive service connection was justified, or if the veteran in question qualified for the presumption because his boat docked or entered Vietnamese inland waters while he was aboard [18]. VA maintains an evolving list of US Navy and Coast Guard ships associated with Vietnam service and possible exposure to Agent Orange based on military records [18].

In 2015, in a case named Gray v. McDonald, the US Court of Veterans Claims determined that the VA's exclusion of the bays and harbors was an "unsupported legal fiction', saying it was "devoid of any indication that the VA made a fact-based assessment of the probability of exposure" [1]. It ordered the VA to go back and reevaluate the definition of inland waterways as it applied to bays and harbors. The VA did so and decided to still exclude bays and harbors. Moreover, it revised its internal manual directing the VA claims adjudicators to exclude service in bays and harbors from the Agent Orange presumption $[1,19]$.

Lastly, a new legislative fix has been proposed by Congress, “The Blue Water Navy Vietnam Veterans Act of 2017” [HR 299]. This act, if enacted is would fix the 20-year old misapplication of the law that functionally restricted Blue Water Veterans from receiving benefits if they had served in bays, harbors and territorial seas of Vietnam [1]. The act would potentially affect 90,000 veterans at a cost of approximately $\$ 1.1$ billion.

\section{A Basis for Common Sense Actions}

The real debatable issue that justifiable galls Blue Water Navy veterans is that public discussions and governmental actions related to Agent Orange have proceeded largely on the assumption, rather than the determination, of widespread substantial exposure to Agent Orange to veterans of the Vietnam War. In other words, the perception of how Agent Orange was handled and sprayed in Vietnam has been based on a false premise [20]. Accordingly, VA has used a "political" definition for exposure for Vietnam Veterans; for instance, if a US veteran served in Vietnam, even for one day, that individual is considered "exposed" to Agent Orange. The veteran is therefore eligible for presumptive compensation for any of 14 diseases determined by the Institute of Medicine and accepted by the VA to be associated with exposure to Agent Orange and/or its dioxin contaminant [20]. The extensive medical and scientific studies of Agent Orange and associated TCDD and the critical examination of historical records over the last thirty-five years, tell us that most veterans were not exposed to Agent Orange, and those that were exposed, received only negligible doses. Nevertheless, as Vietnam veterans have aged, the presence of diseases have increased [20].

To make this more concerning to Blue Water Veterans is that VA is now acknowledging that veterans who served on the Korean $\mathrm{DMZ}$ and in Thailand are eligible as are some veterans who served in Guam and Okinawa during the war, and in all these cases there was a complete lack of historical data to substantiate their exposure [20]. 
Logic and common sense should tell us that when a PRESUMPTION is used to prove a fact, one has departed from the scientifically accepted standard of "cause and effect." Such a study seeking cause and effect was the 20-year Air Force Health Study, the premier epidemiologic study of the 1268 men of Operation RANCH HAND, and their 5:1 matched cohort. Dioxin (TCDD) levels in many of these men exceeded 600 parts per trillion, clearly confirming heavy exposure [21]. Yet the conclusion of the 20-year study was that there was no evidence of disease (more than 300 endpoints examined) caused by their elevated levels of exposure to Agent Orange [21]. The Center for Disease Control and Prevention's (CDC's) 30-year follow-up of 9,300 US Army veterans who had served in Vietnam, and whose presumption of exposure would have been consistent with VA policy, found that their health was no different than their match cohort of 9,000 Army veteran who did not go to Vietnam [22].

So, what do all these observations have to do with the Blue Water Navy? The Agent Orange Act of 1991 was very poor public policy, and perhaps Congress and DVA could have been fairer to all Vietnam veterans including Blue Water Navy veterans with a program of 'Vietnam experience' benefits rather than Agent Orange benefits. However, in the absence of such a reasoned policy, one can conclude that the VA's current policy for providing compensation in the absence of exposure for "boots on the ground" veterans of the Vietnam War, should be extended through Congressional action to Blue Water Navy veterans.

It is my hope that ongoing public dialog can result in a more reasoned policy for all Vietnam veterans, including Blue Water Navy veterans.

\section{Acknowledgements}

The author acknowledges the US Department of Veterans Affairs for funding an effort for the author to spend two years (20122014) in the National Archives developing a massive database and preparing reports of documents found on all aspects of the development and testing of the tactical herbicides, their transport, health impacts and policies in the war in Southeast, 1961-1975.

\section{References}

1. MOAA (2018) Blue Water Navy and Agent Orange: Taking the Fight to the Courts. Military Officers Association of America Magazine.

2. Panangala SV, Shedd DT (2014) Veterans Exposed to Agent Orange: Legislative History, Litigation, and Current Issues. CRS Report 7-5700, Congressional Research Service, United States Congress, Washington DC, USA.

3. Young AL, Cecil PF Sr, Guilmartin JF Jr (2004) Assessing Possible Exposure of Ground Troops to Agent Orange During the Vietnam War: The Use of Contemporary Military Records. Environ Sci Pollut Res Int 11: 349-58

4. Cecil PF Sr (1986) Herbicidal Warfare: The RANCH HAND Project in Vietnam. Praeger Special Studies, Praeger Scientific, New York, NY, USA.

5. Young AL, Young KL (2013) Discussion Points Concerning Blue Water Navy Claims. Agent Orange Brief No. 2, Compensation Service, Department of Veterans Affairs, 810 Vermont Ave, NW, Washington DC.

6. IOM (2011) Blue Water Navy Veterans and Agent Orange Exposure. Institute of Medicine, Health and Medicine Division, National Academies of Sciences, Washington DC, USA.

7. Rossie JP, Melninkaitis RG (2012) Dioxin on the Carriers: The Contamination of Aircraft Carriers and Their Crews in the Gulf of Tonkin. Blue Water Navy Vietnam Veterans Association, PO Box 1035, Littleton, CO, 80160, USA.

8. Wells JB (2017) Military-Veterans Advocacy: Written Testimony for the Record, submitted to the United States House of Representatives Disability and Memorial Affairs Subcommittee of the Veterans Affairs Committee.

9. Ornstein C, Parris T Jr, Hixenbaugh M (2015) 40 Years After Vietnam, Blue Water Navy Vets Still Fighting for Agent Orange Compensation. Reliving Agent Orange Series, ProPublica, The Virginian-Pilot.

10. Westing AH (1976) Ecological Consequences of the Second Indochina War. Stockholm International Peace Institute. Almqvist \& Wiksell International, Stockholm, Sweden.

11. Young AL, Van Houten WJ, Andrews WB (2008) 2nd Agent Orange and Dioxin Remediation Workshop, Hanoi, Viet Nam, 18-20 June 2007. Environ Sci Pollut Res Int 15: 113-8.

12. Tschirley FH (1968) Response of Tropical and Subtropical Wood Plants to Chemical Treatments. Report CR-13-67, Agricultural Research Service, US Department of Agriculture, Washington DC, USA.

13. Crosby DG, Wong AS (1977) Environmental Degradation of 2,3,7,8-Tetradibenzo-p-dioxin (TCDD). Science 195: 1137-8.

14. Hoffman T, Wendelborn A (2007) Colloid Facilitated Transport of Polychlorinated Dibenzo-p-dioxins and Dibenzofurans (PCDD/Fs) to the Groundwater at Ma Da Area, Vietnam. Environ Sci Pollut Res Int 14: 223-34.

15. Young AL, Newton M (2004) Long Overlooked Historical Information on Agent Orange and TCDD Following Massive Applications of 2,4,5-T-Containing Herbicides. Environ Sci Pollut Res Int 11: 209-21.

16. Young AL, Thalken CE, Carney W (1979) Herbicide Orange Site and Environmental Monitoring: Summary and Recommendations for Naval Construction Battalion Center, Gulfport, MS, TR-OEHL-169, Occupational and Environmental Health Laboratory, Brooks Air Force Base, Texas, USA.

17. Piazza R, Giuliani S, Bellucci LG, Mugnai C, Nguyen Huu Cu, et al.(2010) PCDD/Fs in Sediments of Central Vietnam Coastal Lagoons: In Search of TCDD. Mar Pollut Bull 60: 2303-10.

18. DVA (current) Blue Water Veterans and Agent Orange Exposure, Department of Veterans Affairs, Washington DC, USA.

19. DVA (2015) Health Care. Department of Veterans Affairs, Washington DC, USA.

20. Young AL, Young KL (2017) Agent Orange Use in Vietnam and Alleged Health Impacts: A Review. Med Res Arch 5 (10): 1-20.

21. Buffler PA, Ginevan ME, Mandel JS, Watkins DK (2011) The Air Force Health Study: An Epidemiologic Retrospective. Ann Epidemiol 21: 673-87.

22. Boehmer TK, Flanders WD, McGreehin MA, Boyle C, Barret DH (2004) Postservice Mortality in Vietnam Veterans: A 30-Year Follow-up. Arch Intern Med 164: 1908-16. 


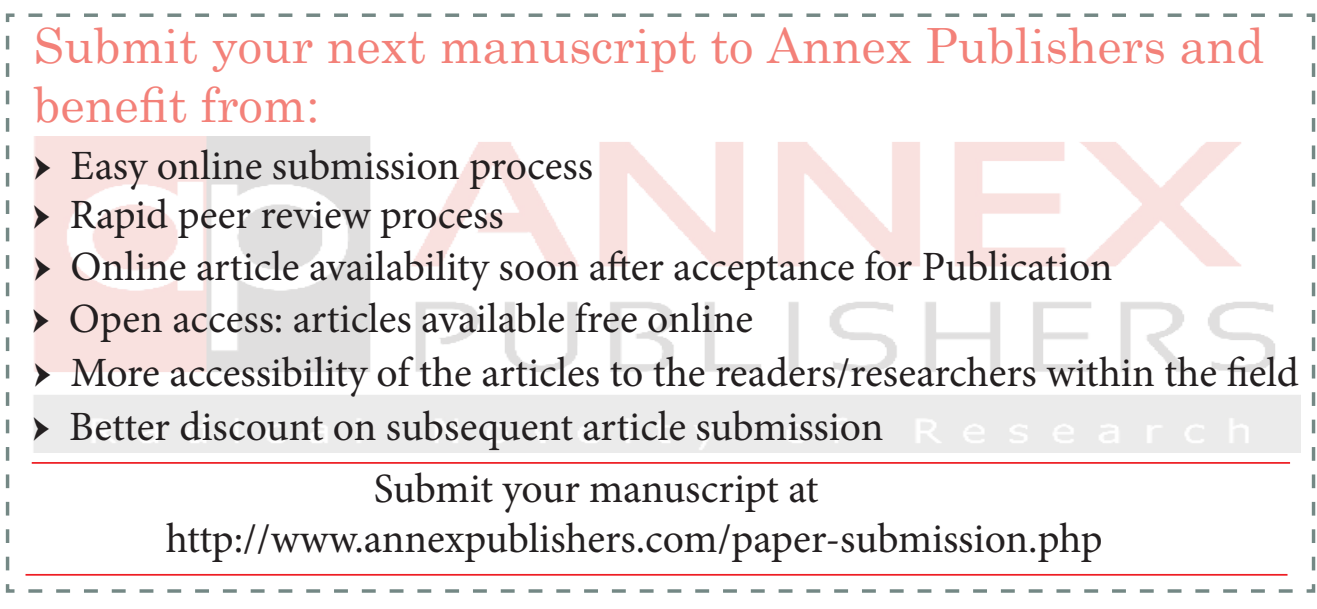

